Ліганенко Маргарита Геннадіївна кандидат технічних наук, доцент кафедри туристичного бізнесу та рекреації, Одеська національна академія харчових технологій, вул. Канатна, 112, м. Одеса, 65039, тел.: (048) 720-91-93, e-mail: margie88svet@gmail.com, https://orcid.org/0000-0002-4509-4616

Шепелева Ольга Валеріївна аспірант кафедри туристичного бізнесу та рекреації, Одеська національна академія харчових технологій, вул. Канатна, 112, м. Одеса, 65039, тел.: (048) 720-91-93, e-mail: shepelevaolga1313@gmail.com, https://orcid.org/0000-0003-4128-2094

Мішкевич Катерина Олександрівна магістр другого року кафедри туристичного бізнесу та рекреації, Одеська національна академія харчових технологій, вул. Канатна, 112, м. Одеса, 65039, тел.: (048) 720-91-93, e-mail: katusha42011@gmail.com

\title{
АНАЛІЗ МОЖЛИВОСТЕЙ ФІТНЕС-ТУРІВ В УКРАЇНІ ТА ОДЕСЬКІЙ ОБЛАСТІ
}

Анотація. В останні роки отримав розповсюдження особливий вид спеціалізованого туризму - фітнес-туризм, через популярність оздоровлення i підтримання фізичної форми. Поява фітнес-турів на ринку туристичних послуг - це вигідна заміна пасивному пляжному відпочинку. Фітнес-тури проходять в тих же природних умовах, але дають більше можливостей для фізичного та емоційного розвитку і являються сучасним видом спортивнооздоровчого туризму. Головна мета періоду відновлення в період відпустки це відпочинок, позитивні емоції і рухова активність. Залежно від мети туру, напрями можуть бути різноманітними, іноді виключно релаксаційні або навпаки. Також існує класифікація фітнес-турів на: вузькоспеціалізовані та комбіновані. Доволі часто в програмі фітнес-турів $є$ й танцювальні напрямки. Проте одним із найбільш популярних видів фітнес-турів $є$ йога-тури. До програм фітнес-туру можуть також входити тренінги, семінари по новим видам фітнесу та комплексу вправ, практикуми, майстер-класи, насичені анімаційні i екскурсійні програми. Фітнес-тури на українському туристичному ринку з'явилися відносно недавно, але їх популяризація відбувається досить швидкими темпами серед любителів активного відпочинку.

Туристична індустрія фітнес-турів - це глобальний проєкт, що постійно розвивається та удосконалюється, оскільки потреби у подорожах, оздоровленні та відкритті нових маршрутів постійно зростають з року в рік. Фітнес-турист - це вимогливий мандрівник, який потребує нових туристичних послуг та позитивних та ефектних емоцій від кожної подорожі. 
Як відомо, попит породжує пропозиції. Поява нових пропозицій у туристичній сфері приводить до створення нових фітнес-турів 3 широким спектром послуг. Під час такого відпочинку турист також отримує комплекс практичних знань від фахівців у галузі фітнесу, що допоможе у подальшому вести здоровий спосіб життя, правильно тренуватися, корегувати власну масу тіла. Фітнес-тур може бути корисним для тих, хто бажає розширити коло спілкування, адже групи комплектуються із людей, які об'єднані спільним захопленням. Таке тлумачення вимагає вивчати фітнес як багатогранну дефініцію, яка має значно більший спектр ознак, ніж просто рівень фізичної готовності.

Ключові слова: спортивно-оздоровчий туризм, фітнес-тренди, фітнестури, фітнес-туризм, туризм.

Liganenko Margaryta Hennadiivna Candidate of Technical Sciences, Associate Professor of the Department of Tourism Business and Recreation, Odessa National Academy of Food Technologies, Odessa, 65039, Kanatna St., 112, tel.: (048) 720-91-93, e-mail: margie88svet@gmail.com, https://orcid.org/0000-0002-4509-4616

Shepeleva Olga Valeriivna Graduate student of the Department of Tourism Business and Recreation, Odessa National Academy of Food Technologies, Kanatna St., 112, Odessa, 65039, tel.: (048) 720-91-93, e-mail: shepelevaolga1313@gmail.com, https://orcid.org/0000-0003-4128-2094

Mishkevych kateryna oleksandrivna Master of the Second Year of the Department of Tourism Business and Recreation, Odessa National Academy of Food Technologies, Kanatna St., 112, Odessa, 65039, tel.: (048) 720-91-93, e-mail: katusha42011@gmail.com

\title{
ANALYSIS OF FITNESS TOUR OPPORTUNITIES IN UKRAINE AND ODESSA REGION
}

\begin{abstract}
In recent years, a special type of specialized tourism has become widespread - fitness tourism, due to the popularity of rehabilitation and fitness. The emergence of fitness tours in the market of tourist services is a profitable replacement for passive beach recreation. Fitness tours are held in the same natural conditions, but provide more opportunities for physical and emotional development and are a modern type of sports and health tourism. The main purpose of the recovery period during the holidays is rest, positive emotions and physical activity. Depending on the purpose of the tour, the directions can be varied, sometimes exclusively relaxing or vice versa. There is also a classification of fitness tours into: highly specialized and combined. Quite often in the program of fitness tours there are also dance directions. However, one of the most popular types of fitness tours is yoga tours. The programs of the fitness tour may also include trainings, seminars on new types of fitness and a set of exercises,


workshops, master classes, rich animation and excursion programs. Fitness tours on the Ukrainian tourist market appeared relatively recently, but their popularization is quite fast among fans of active recreation.

The fitness tour industry is a global project that is constantly evolving and improving, as the need for travel, recuperation and the discovery of new routes is constantly growing from year to year. A fitness tourist is a demanding traveler who needs new travel services and positive and effective emotions from each trip. As you know, demand generates supply. The emergence of new proposals in the field of tourism leads to the creation of new fitness tours with a wide range of services. During such a vacation, the tourist also receives a set of practical knowledge from fitness experts, which will help in the future to lead a healthy lifestyle, exercise properly, adjust your own body weight. A fitness tour can be useful for those who want to expand the circle of communication, because the groups are made up of people who are united by a common hobby. This interpretation requires the study of fitness as a multifaceted definition that has a much wider range of characteristics than just fitness.

Keywords: sports and health tourism, fitness trends, fitness tours, fitness tourism, tourism.

Постановка проблеми. Фітнес-тури, які $\epsilon$ дуже популярними у розвинутих країнах - це зовсім інший підхід до відпочинку, під час якого турист отримує не тільки задоволення від подорожі, але й суттєвий рекреаційний ефект. Це також достойна заміна пасивного пляжного відпочинку, яка відбувається у природних умовах, але надає більше можливостей для фізичного та емоційного розвитку. Фітнес-тури на українському туристичному ринку з'явилися відносно недавно, але їх популяризація відбувається досить швидкими темпами серед любителів активного відпочинку. Динамічний розвиток фітнес-сфери вимагає від фітнес-клубів та фітнес-тренерів постійно слідкувати за новинками та впроваджувати їх у свою діяльність, щоб залишатися конкурентоспроможними. Місії фітнесу саме забезпечувати здоров'я нації, а тому потрібно максимально розширювати культуру фітнесу в усіх містах України. Також слід відмітити проблему сертифікації тренерів.

Аналіз останніх досліджень і публікацій. Аналіз досліджуваної літератури свідчить про те, що на сьогоднішній день фітнес-тури являються новим напрямком активного відпочинку, їх популярність росте 3 кожних роком у різних країнах світу. Авторами зроблено моніторинг основних публікацій відомих вчених: К. Купера, Д. Сорренсон, Д. Міллер, Е. Хоулі і Б. Френкс, В.Е. Борилкевич. Які зауважують, що фітнес індустрія стрімко розвивається у всьому світі завдяки комерційній орієнтації, а тенденції у сфері фітнесу швидко змінюються. На конференції «Сучасний стан фітнесіндустрії України і перспективи ії розвиток» та презентації «Дослідження ринку фітнес-послуг України», що були проведені 26 червня 2018 року у Києві, експерти-практики зазначили деякі позиції, які слід розвивати в 
Україні, і які зможуть стати трендовими у майбутньому: тренди ринку споживачів (дитячо-юнацький спорт та фітнес); тренди ринку праці, де відбувається перерозподіл та зростання відповідальності фахівців і взагалі зміна ролі фітнес-тренера; тренди інфраструктури, де наголошує на необхідності державно-приватного партнерства та розвитку муніципальних ініціатив за законодавчої підтримки держави; тренди фітнесу, де виділяє популярність фітнесу саме для схуднення.

Мета статті. Статтю присвячено вивченню такому питанню, як характеристика нового виду спортивно-оздоровчого туризму, а саме фітнестуру. Метою є аналіз існуючих можливостей організації фітнес-турів в Україні та Одеській області, використовуючи сучасні методи оцінювання.

Виклад основного матеріалу. Одним з основних найбільш ефективних напрямків розвитку туристичного ринку, власне, і є спортивний-оздоровчий туризм - всеосяжна форма оздоровчого, пізнавального туризму і подорожей, наслідок та причина таких суспільних тенденцій як здоровий спосіб життя та мода [1]. Популярність оздоровлення і підтримання фізичної форми в сучасних умовах настільки велика, що в останні роки отримав розповсюдження особливий вид спеціалізованого спортивного туризму фітнес-туризм. Фітнес-тур (від «фітнес», англ. fitness від to fit - бути у гарній формі), це вид туризму, основною метою якого $\epsilon$ фізичне й ментальне (психологічне) оздоровлення туриста за допомогою спеціальних методик, які включають фізичні вправи аеробіки, аква-аеробіки, силових занять, танців, пілатесу, йоги та ін., а також - дієту. Ідея проведення фітнес-турів виникла як альтернатива пасивному пляжному відпочинку [1]. В Україні організацією фітнес-турів займаються як професійні фітнес-клуби, так і туристські фірми. Для організації таких подорожей вони, як правило, об'єднують свою роботу. Таке співробітництво надає можливість розробки якісного й затребуваного туристського продукту [1].

За результатами 2018 року командою FitnessConnectUA виявлено 1765 об'єктів фітнес-індустрії, більшість яких відповідають параметрам фітнесклубу. Фітнес-клуби в основному розташовані у великих містах: Київ, Харків, Одеса, Дніпро, Львів, Запоріжжя. Дослідження попередніх років відображали вигідність відкриття фітнес-об'єктів у містах 3 населенням менше 500 тис осіб, а дані 2018 року відобразили цю тенденцію в цифрах [2].

Міжнародний звіт European Health\&Fitness Market показав, що фітнесом у Європі сьогодні займається 62,2 млн громадян, у тому числі 1,2 млн українців. Але якщо говорити про покриття фітнес-послугами, то в Україні цей показник складає менше $3 \%$ i $є$ одним iз найнижчих в Європі. Засмучуватись цим фактом не варто, адже фітнес в Україні зародився років на 20 пізніше, ніж в більшості європейських країн [3].

За кількістю фітнес закладів Україна на 11 позиції у Свропі. В нашій країні дохід від фітнес-послуг становить 266,5 млн євро, а до занять фітнесом в Україні залучено 1,2 млн осіб, що становить 2,9\% населення. Цей 
показник значно нижче провідних європейських фітнес-країн, однак свідчить про значний потенціал розвитку індустрії. В Україні фітнесом займаються рівноцінно жінки (50\%) і чоловіки (50\%). Найбільш активними членами фітнес клубів є особи зрілого віку, зокрема 17\% учасників занять фітнесом особи 31-35 років. Найменш залученою до занять фітнесом $\epsilon$ молодь юнацького віку (6\% юнаків та дівчат 18-21 року), а також люди старше 50 років (11\%). Це пояснюється несхильністю молоді купувати абонементи в фітнес клуби, віддаючи перевагу екстремальним та рекреаційним видам рухової активності. Щодо людей похилого віку, то у більшості з них не сформована культура фітнесу та розуміння його необхідності. Але з часом стануть старше люди, які зараз активно залучені до занять фітнесом. При виборі фітнес клубу в Україні споживачі звертають увагу на вартість абонементу (29\% опитаних), доступність (20\%), наявність басейну та спапослуг (12\%), якість обладнання (11\%), кількість клубів (8\%), професіоналізм тренерів (7\%), асортимент послуг (6\%), рівень обслуговування (4\%) та рекламу (2\% опитаних) [2].

Сфера фітнесу динамічно розвивається, тому цикл періоду існування (від зародження та розповсюдження до піку популярності та спаду) одного напрямку фітнесу може бути менше 10 років. Це пов’язано, у першу чергу, 3 розробкою додаткового спорядження для фітнесу, на основі використання якого з'являються нові напрямки фітнесу. Так, в Україні порівняно недавно почали використовувати платформу Procedos, SUP-платформу, ViPR, TRX Rip, костюми для EMS-фітнесу, що призводить до появи та розвитку нових напрямків фітнесу.

2020 рік став одним з найбільш пам'ятних, оскільки зміни, які слідували у всіх сферах та галузях економіки принесли нові тенденції та змусили багатьох шукати нові шляхи до покращення та продовження свого розвитку. Особливо це торкнулося працівників фітнес-індустрії. Пандемія COVID-19, яка охопила світ, змінила все.

Конкурентоспроможність туристичного продукту характеризується системою критеріїв, які спонукають споживача вибрати конкретну організацію і його послуги. Конкурентна сила споживачів полягає в тому, що вони визначають попит. Ці конкурентні сили чинять тиск на організацію та визначають можливості iі подальшого розвитку. У вітчизняній практиці проводиться робота 3 удосконалення системи програмного забезпечення сфери оздоровчої фізичної культури. Так, розроблено і кваліфікаційну характеристику фахівця 3 рекреації й оздоровчої фізичної культури відповідно до державних законів України, а також iз урахуванням Української класифікації професій, затвердженої Міністерством праці України, Міжнародною стандартною класифікацією освіти та Міжнародною стандартною класифікацією професій [4]. Найбільш відомі фітнес-тури по Україні представлені у таблиці 1. 
Пропозиції по фітнес-турам України

\begin{tabular}{|c|c|c|c|}
\hline $\begin{array}{l}\text { Назва туру, } \\
\text { організатори }\end{array}$ & $\begin{array}{l}\text { Географія } \\
\text { розміщення }\end{array}$ & Проживання, кількість днів & $\begin{array}{l}\text { Вартість, } \\
\text { грн. }\end{array}$ \\
\hline $\begin{array}{l}\text { Проєкт «Стрункі та } \\
\text { молоді», фітнес-тренери } \\
\text { Жолнер Інна, Ірина } \\
\text { Федотова }\end{array}$ & $\begin{array}{l}\text { Жденієво, } \\
\text { Закарпатська } \\
\text { область }\end{array}$ & $\begin{array}{l}9 \text { днів, готель Рейкарц } \\
\text { Карпати 4* }\end{array}$ & $\begin{array}{l}19440 \text { грн } \\
\text { (для жінок } \\
\text { група до } \\
18 \text { осіб) }\end{array}$ \\
\hline
\end{tabular}

Програма туру: - проживання в готелі Рейкарц Карпати 4 *; - повноцінне 3-х разове харчування: сніданок, обід, вечеря; - лекції по харчуванню Світлани Фус; робочий зошит з особистим розкладом; - 2-3 тренування в день; групові тренінги 3 психології; -майстер клас по самооцінці; -психологічні ігри;- індивідуальна консультація психолога; - індивідуальне тренування TRX або флай йога; -щоденне відвідування басейну і сауни; -мотузкове містечко; - 1 похід в гори на 1/2 дня; - Гала вечірка, приємні сюрпризи і подарунки.

\begin{tabular}{|l|l|l|l|}
\hline $\begin{array}{l}\text { Школа «Здорового } \\
\text { харчування» }\end{array}$ & Закарпаття & $\begin{array}{l}\text { Проживання в міні-готелі } \\
\text { класу «Люкс-комфорт», } \\
\text { днів }\end{array}$ & $\begin{array}{l}\text { Стандарт } \\
14 \text { 650 грн } \\
\text { Стандарт } \\
\text { плюс } \\
20 \text { 250 грн } \\
\text { (група до } \\
15 \text { осіб) }\end{array}$ \\
\hline
\end{tabular}

Програма туру: Трансфер від станції Карпати або Мукачево (і назад) комфортабельний транспорт; - Проживання в гостьовому будинку класу Люкскомфорт в наймальовничішому місці санаторної зони Закарпаття, в затишних номерах - 9 днів.

Індивідуально: - Навчання від експертів Школи Харчування - лекції (4) i майстер-класи (5) (за програмою туру)- 6 разове збалансоване харчування за авторською системою «Схуднемо комфортно і назавжди», тільки з еко-продуктів від велнес-кухаря; - Походи в гори з персональним гідом; - Різноманітні тренування від фітнес-тренера міжнародного класу. Гарантія ефективності i результату 11 тренувань; -Консультація дієтолога «Велнес-оцінка - ваша композиція тіла i індивідуальний розрахунок білків, жирів і вуглеводів». Рекомендації по запуску ліполізу (спалювання жирів); - Вечір знайомств і заключний банкет зі святковими велнес-закусками, подарунками, сюрпризами, цікавою програмою і дискотекою; Щоденні сеанси в Енергетичній Інфрачервоної Сауні і Енергетичної Інфрачервоної лампою - Ефект Детокс, омолодження, жироспалювання, вироблення колагену i підтяжки шкіри Карпатська Баня з масажем березовими віниками і кавово-сольовим пілінгом; - Комплексна програма «Корекція фігури» або «Здорова спина»; Комплексна програма догляду у косметолога; - Екскурсії (за програмою туру)

\begin{tabular}{|l|l|l|l|}
$\begin{array}{l}\text { ForFitAcademy, фітнес- } \\
\text { тренер } \\
\text { Сергій Фальштинський }\end{array}$ & $\begin{array}{l}\text { Буковель, } \\
\text { Івано- } \\
\text { Франківська } \\
\text { область }\end{array}$ & $\begin{array}{l}\text { Готель «Ведмежий двір», } \\
\text { днів }\end{array}$ & $\begin{array}{l}18 \text { 163 грн } \\
\text { (група до } \\
12 \text { осіб) }\end{array}$ \\
\hline
\end{tabular}

Програма туру: - Трансфер; - тренування різного рівня інтенсивності 2-3 на день; - екскурсії до гори Хом'як, Говерла, - екскурсія в Яблуниці; - екскурсія на підйомник; - вело-екскурсія до водоспаду Пробій; - вечірні лекції та консультації 3 правильного харчування; - катання на квадроциклах 
Не зважаючи на те, що український ринок у напрямі фітнес-індустрії тільки розвивається, вже існує достатньо цікавих пропозицій від передових фахівців фітнесу та оздоровлення, які в основному направлені на такі зони відпочинку, як Буковель, Моршин, Яремча, Жденієво, Затока.

Найважливішим етапом при формуванні стратегї розвитку туризму в країні (регіоні, місті) є стратегічний i конкурентний аналіз. Одним із інструментів стратегічного аналізу виступає SWOT-аналіз. Цей універсальний метод особливо ефективний при аналізі переваг і недоліків туристичного ринку країни. На основі результатів стратегічного аналізу виробляються пріоритети розвитку туризму, а також частині стратегії протидії негативним факторам.

Проведено SWOT - аналіз розвитку українських фітнес-турів. Окремі фрагменти SWOT - аналізу представлені нижче у таблиці 2.

Таблиия 2

SWOT- аналіз розвитку фітнес-турів в Україні

\begin{tabular}{|c|c|}
\hline & \\
\hline $\begin{array}{l}\text { дуальний підхід до групи } \\
\text { нням усіх особливостей групи } \\
\text { ньо велика кількість людей } \\
\text { зація під керівництвом фахівці }\end{array}$ & $\begin{array}{l}\text { Іня, щодо фітнес-турів; } \\
\text { днення появи нових фітнес- } \\
\text { швидка зміна фітнес-трендів; } \\
\text { тність державних програм } \\
\text { пки спорту та фітнесу; } \\
\text { ий рівень попиту на } \\
\text { Ічний продукт } 3 \text { боку } \\
\text { ення на території регіону } \\
\text { зних конференцій, фітнес- } \\
\text { цій, виставок; } \\
\text { чна кількість постачальників } \\
\text { фітнес-туризму; }\end{array}$ \\
\hline
\end{tabular}




\begin{tabular}{|c|c|}
\hline Можливості & Загрози \\
\hline 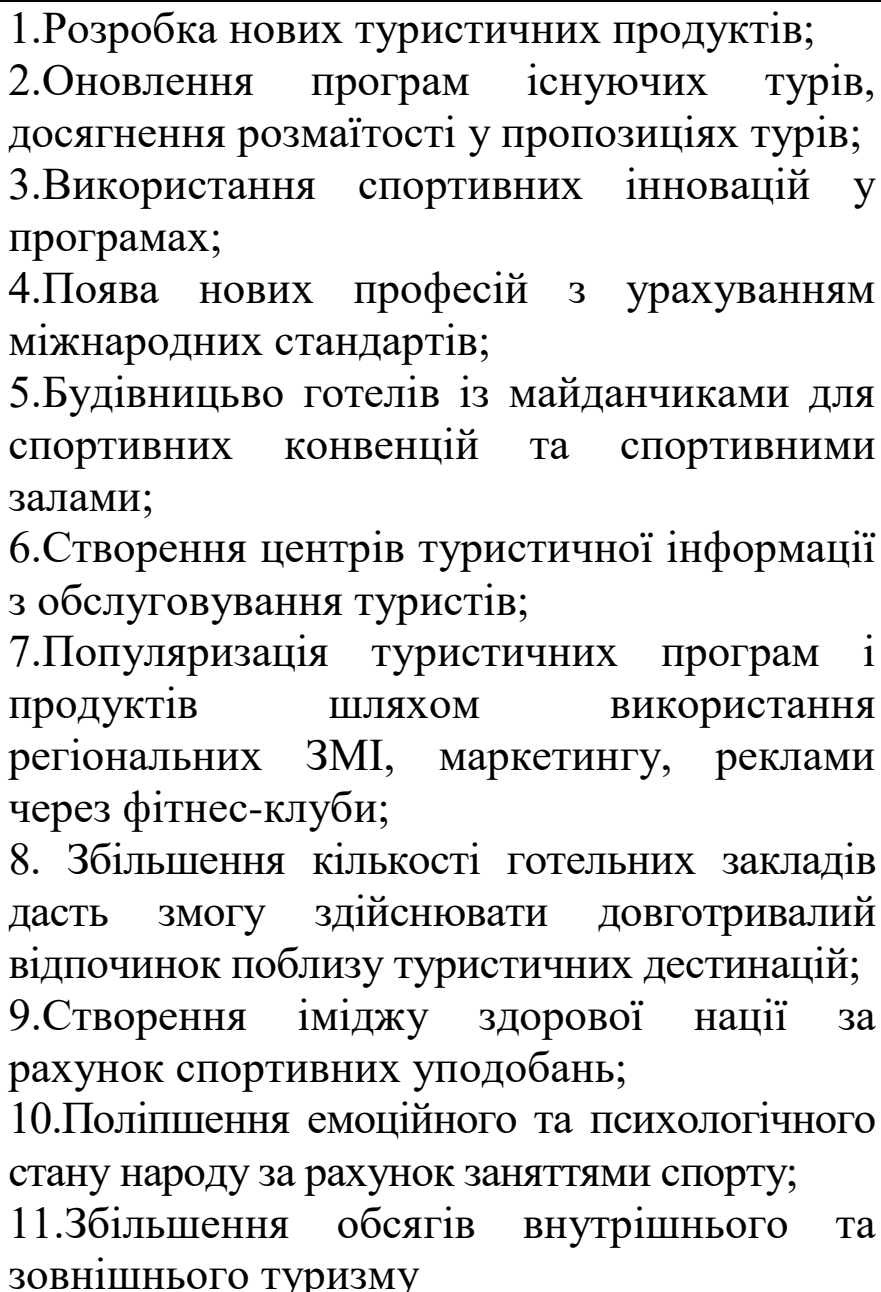 & $\begin{array}{l}\text { 1.Недостатнє фінансування } 3 \\
\text { державного бюджету нових } \\
\text { туристичних програм; } \\
\text { 2.Недостатня кількість готелів для } \\
\text { проведення фітнес-турів; } \\
\text { 3.Спад в економіці, політична криза, } \\
\text { світова фінансова криза; 4.Недостатнє } \\
\text { користування заходами рекламно- } \\
\text { інформаційного характеру; } \\
\text { 5.Слабке позиціонування } \\
\text { регіонального туристичного продукту } \\
\text { на зовнішніх туристичних ринках; } \\
\text { 6.Припинення розвитку спортивного } \\
\text { туризму на Україні } \\
\text { 7.Зниження платоспроможного } \\
\text { попиту населення; } \\
\text { 8. Поширення корона вірусної } \\
\text { інфекції СОVID-19 }\end{array}$ \\
\hline
\end{tabular}

* складено авторами

В результаті проведеного дослідження, встановлено співвідношення переваг і слабкостей, можливостей і загроз таблиця 3.

Таблиия 3

Показники внутрішнього та зовнішнього середовища

\begin{tabular}{|c|c|c|}
\hline Показник & Кількість & Співвідношення \\
\hline Сильні сторони & 15 & Сильні сторони $>$ Слабкі сторони \\
\hline Слабкі сторони & 9 & \\
\hline Можливості & 11 & Можливості > Загрози \\
\hline Загрози & 8 & \\
\hline
\end{tabular}

Сильні сторони фітнес-турів - це переваги, що виділяють цей туристичний напрям серед інших видів турів. Слабкі сторони - це недоліки організації фітнес-турів, що підлягають виправленню, щоб в певній місцевості можна було удосконалювати туристичний процес, залучати більшу кількість туристів. Проаналізувавши сильні сторони фітнес-турів можна сказати, що одними 3 найважливіших пунктів, які варто укріпляти та розробляти це - популяризація фітнес-індустрії за рахунок підтримки спортивних клубів з боку держави, рекламні заходи по розповсюдженню інформації відносно корисності фітнес-турів, будівництво або реконструкція 
готелів із урахуванням спортивних потреб туриста та створення спортивних майданчиків для фітнес-конвенцій, активне використання регіональних програм розвитку туризму в Одеській області; більш активна популяризація фітнес-конвенцій, як спеціалізованих засобів розповсюдження фітнесу інноваційного туристично-рекреаційного продукту, створення для них реклами. Аналізуючи слабкі сторони фітнес-турів, бачимо, що найбільш суттєвими є: висока вартість турів (на 30-50\%); недостатня популяризація фітнес-турів, зосередженість фітнес-індустріі тільки у великих містах України; недостатній рівень розвитку туристичної інфраструктури (низький рівень надання послуг; недостатня кількість закладів розміщення та харчування; недостатня кількість спортивного обладнання та відсутність територій для проведення тренувань та фітнес-конвенцій; низький рівень поінформованості населення, щодо фітнес-турів; припинення появи нових фітнес-клубів, швидка зміна фітнес-трендів; відсутність державних програм підтримки спорту та фітнесу; низький рівень попиту на туристичний продукт 3 боку проведення на території регіону спортивних конференцій. Щодо можливостей та загроз треба сказати, що на даний момент можливостей більше ніж загроз, а саме: розробка нових туристичних продуктів; будівництво готелів із майданчиками для спортивних конвенцій та спортивними залами надасть змогу поліпшити емоційний та психологічний стан народу та створення іміджу здорової нації за рахунок спортивних уподобань, що призведе до збільшення обсягів внутрішнього та зовнішнього туризму. Суттєві загрози: зниження платоспроможності населення та висока вартість фітнес-турів знизить попит на розвиток їх пропозицій, а також недостатньо розвинута інфраструктура може привести до зникнення цього виду туризму через спад в економіці, політичної криза, світової фінансової криза; поширення корона вірусної інфекції COVID-19. В Україні зросла тенденція до занять спортом за рахунок збільшення вільного часу на період карантину як у форматі outdoor, так і онлайн, що дало поштовх до пошуку нових спортивних турів, а саме фітнес-напрямку, зокрема по куротносанаторним та оздоровчо-лікувальним рекреаційним територіям України. Отже підводячи підсумки проведеного SWOT - аналізу, можна стверджувати, українські фітнес-тури тільки починають свій шлях до популяризації і являються актуальними на сьогоднішній день.

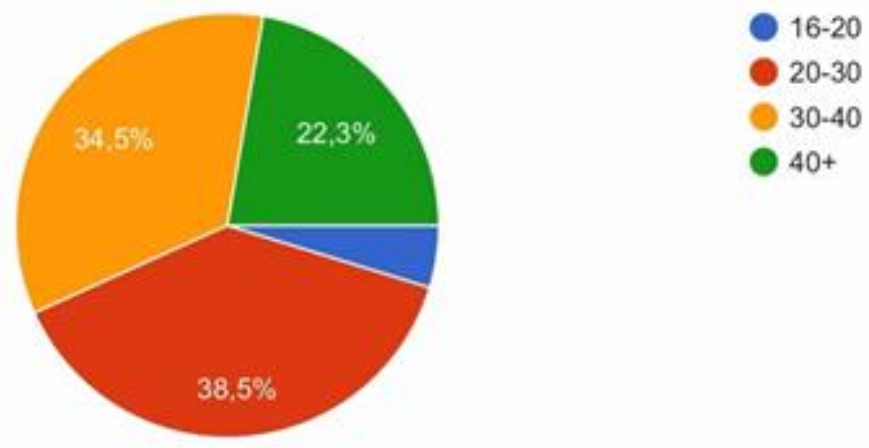

Рис. 1. Результати росподілу опитуванних за віком 
Для того щоб виявити і вивчити потреби клієнтів в організації відпочинку із застосуванням фітнес-технологій, було проведено дослідження. В якості методу дослідження були використані метод соціологічного опитування у додатку Google та метод аналізу. Для його проведення була розроблена анкета. Анкетування пройшли 149 резидента. В опитуванні приймали участь переважно жителі Одеської області. Частина опитаних (38.5\%) це люди у віці від 20 до 30 років, також переважає вік від 30 до 40 років, $(34,5 \%)$, що залишилися розділили між собою віку: $40+$ років $(22.3 \%)$, та від 16 років до 20 (4.7\%) (рис. 2.1). На підставі цих даних рекомендується складати програму туру 3 урахуванням фізіологічних і психологічних особливостей переважаючого віку.

Для того, щоб дізнатися, яке місце займає фітнес в житті людей, було поставлено ряд запитань:

1. Займаєтесь у фітнес клубі? (рис. 2)

2. Скільки разів на тиждень Ви користуєтеся послугами клубу ? (рис. 3).

За результатами опитування займаються - $58,1 \%$, та майже половина $41,9 \%$ не займається у фітнес клубі. Тоді ті, хто відвідують 2-3 рази на тиждень та 3-4 рази поділили однакову кількість відсотків, а саме 24,8 \%, щодня - 11,7\%, один раз в тиждень, і найрідше - 2,1\%

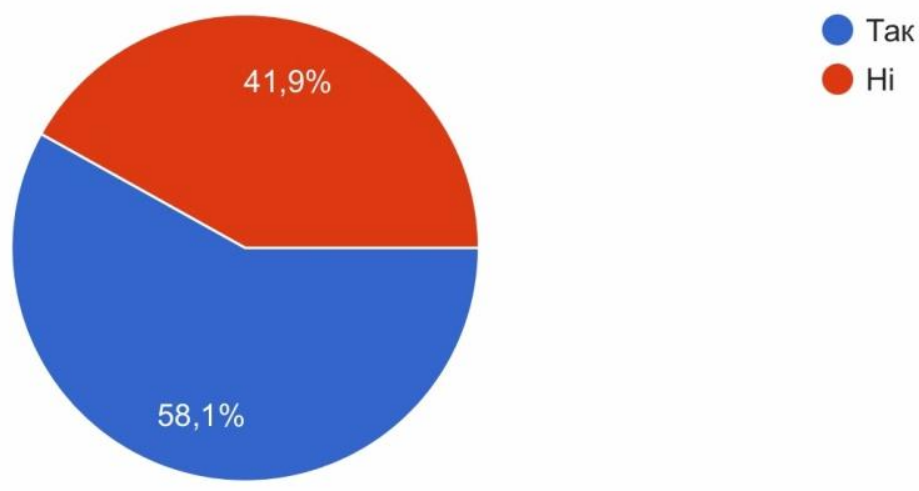

Pис. 2. Чи є резидент членом клубу

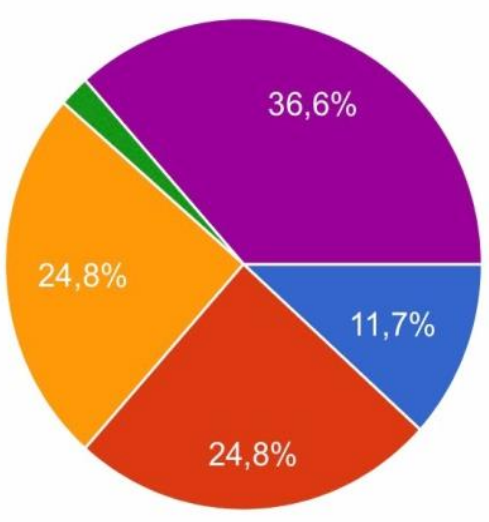

Кожен день

3-4 рази на тиждень

2-3 рази на тиждень

1 раз або інколи ні разу

Не займаюссь

Pис. 3. Аналіз частоти відвідувань фітнес-клубу

Фітнес-туризм - це нове направлення для туризму в цілому, тому нас цікавило: чи знайомий хтось 3 цим напрямком і чи доводилося подорожувати 
таким чином? 61,5\% відповіли, що знайомі з цим поняттям, але ніколи не брали участь, для 20,3\% опитаних цей вид туризму - не знайомий, але $\epsilon$ бажання відправитися на фітнес-тур, 9,5\%, що був в якості учасника фітнестуру і 8,8\% не зацікавлені в такому туризмі (рис.4).

Було цікаво, як резиденти організовують свій відпочинок. Серед представлених варіантів відповідей $64,9 \%$ самостійно розробляють план відпочинку, 45,3\% купують готові поїздки у тур агентстві, також була рядок для самостійного варіанта відповіді, хтось відповів що комбінує, зазвичай нікуди не їздиь, хтось відпочиває перед телевізорами та іграми, та ін.

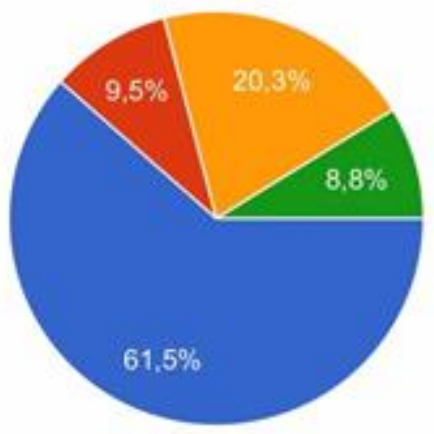

Так, знайоме, але жодного разу не брав(ла) участь у подібному турі Так, знайоме був(ла) в якості учасник: фітнес- туру

Ні, нічого не знаю про цей напрямок в туризмі, але $є$ бажання відвідати фітнес-тур

Мені знайоме це поняття, але не має бажання у цьому приймати участь

Рис. 4. Аналіз опитування стосовно обізнаності поняття «фітнестуризм»

Наступне питання анкети визначив потенційних клієнтів фітнес-туру, які хотіли б провести свій відпочинок у приємному місці, не перериваючи при цьому тренування, з фітнес-програмою під керівництвом тренерів клубу. 80,4\% 3 100\% відповіли «Так». Це дуже добрий показник того, що напрямок фітнес-турів цікавий для людей. І лише 19,6\% дали негативну відповідь (рис. 5).

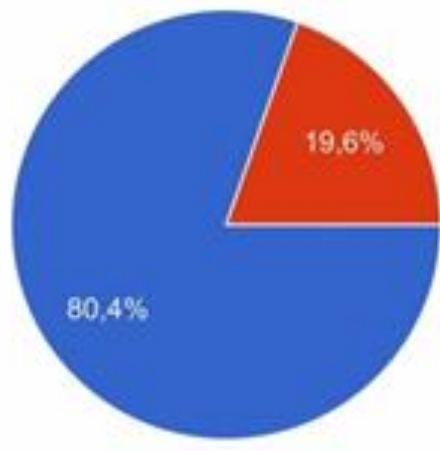

Рис. 5. Бажання респондентів відправитися на відпочинок із застосуванням фітнес-технологій

Бажаними видами тренувань виявилися: аеробіка, кардіо тренування 44,6\% i тренування в тренажерному залі - 39,9\%. На другому місці за важливістю стали пілатес, йога, port de bras, stretching - 37,8\% і танцювальні програми - 35,8\% (рис. 6). 


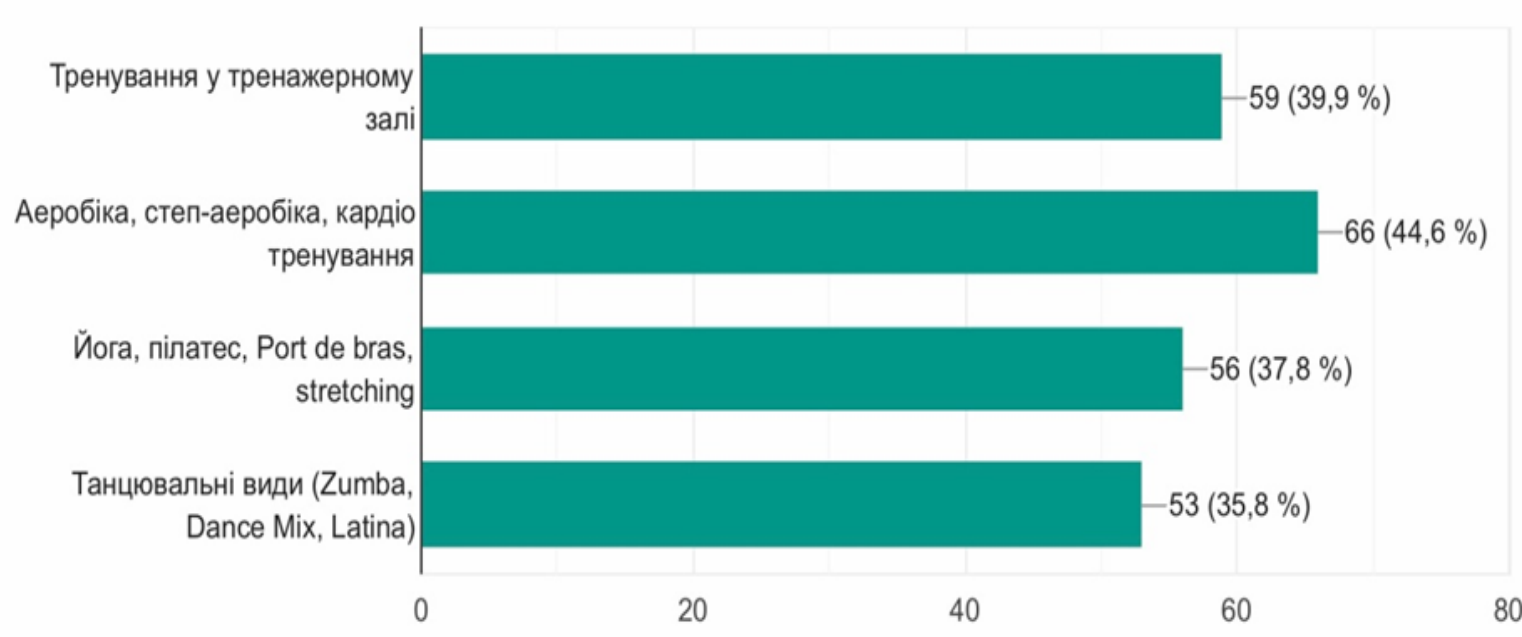

Pис. 6. Переважні види тренувань

Організація і проведення фітнес-туру безпосередньо залежить від цілей, поставлених тренером і учасниками. Щоб отримати ефект від конкретного туру, мета повинна бути конкретно позначена і слідувати 3 соціального замовлення. На думку опитаних, головна мета фітнес-туру - це розвиток фізичних i духовних якостей (пляжний відпочинок + огляд визначних пам'яток + фітнес-тренування), так відповіли 63,5\% респондентів, другий за значимістю стала мета - поліпшення фізичної форми і іï підтримку - 49,3\% i менш значним, на думку респондентів, в фітнес-турі виявився особистісний ріст та самопізнання- 36,5\%. Також вибір: знайомство 3 новими людьми становить - $26,4 \%$. (рис.7).

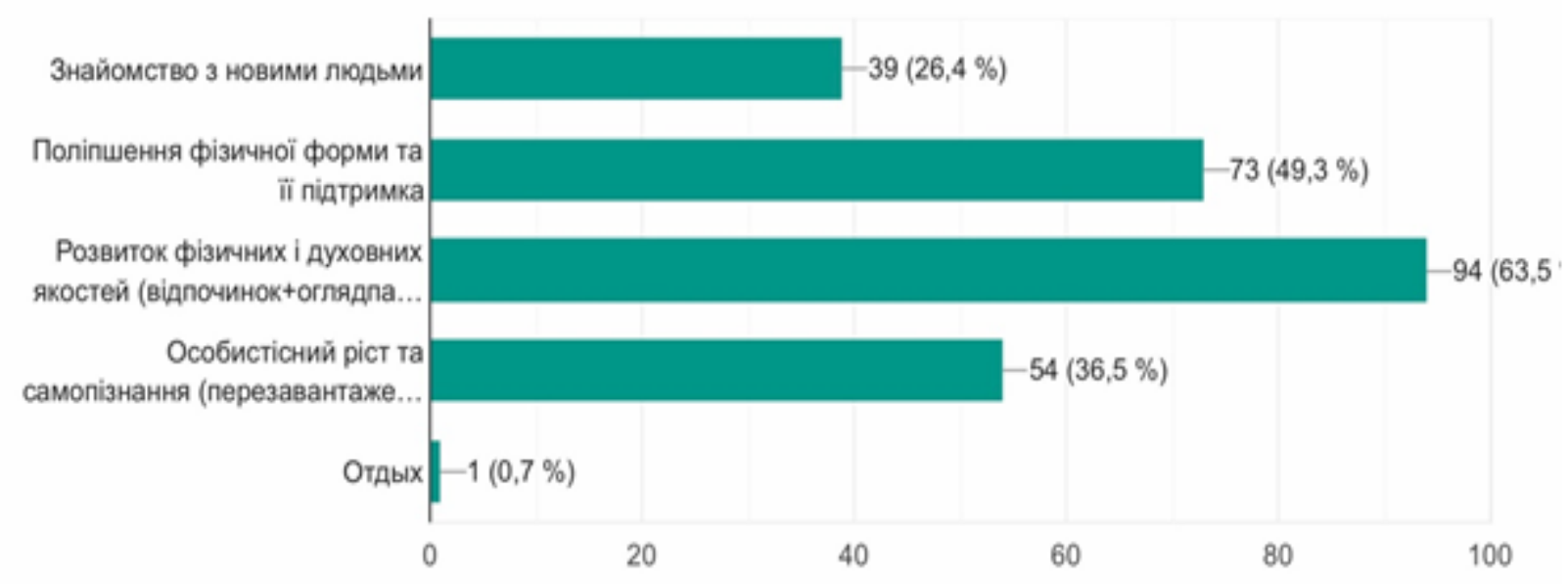

Puc. 7. Мета фітнес-туру

Додаткові послуги, які хотіли б отримати учасники в фітнес-турі: майстер-класи та розваги $(60 \%)$, консультації по харчуванню дієтолога (37,2\%). Також необхідно відзначити, що дехто хотів, крім фітнес-тренувань, відвідувати масаж (рис.8). Дехто міг обійтись і без додаткових послуг. Рекреаційний фітнес-тур може бути підкріплений додатковими послугами. Це дозволить урізноманітнити дозвілля учасників і отримати калейдоскоп вражень. 


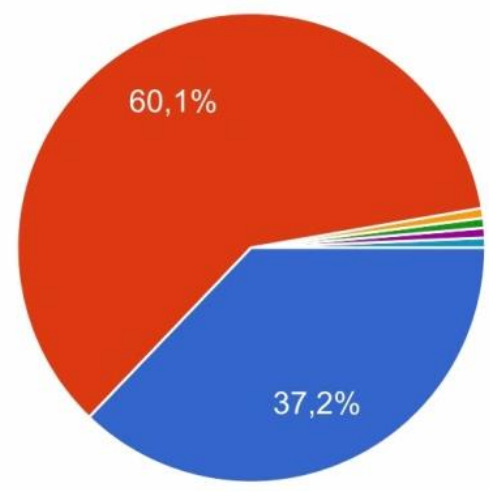

Консультації від дієтолога по харчуванню

Розваги, майстер-класи

Не обязательно

Массаж

И консультация диетолога

Pис. 8. Відношення респондентів до додаткових послуг у фітнес-турах

Ціна, яку учасники готові заплатити за десятиденний фітнес-тур до Фрумушика-Нова, визначила фінансову доступність туру. Багато вибрали діапазон цін в районі 3000-5000 тисяч гривень - 64,2\%, решта 34,5\% опитаних готові заплатити за тур від 5000 до 10000 тисяч гривень і тільки 1,3\% мають можливість купити тур за ціною більше 10000 тисяч гривень (рис. 9).

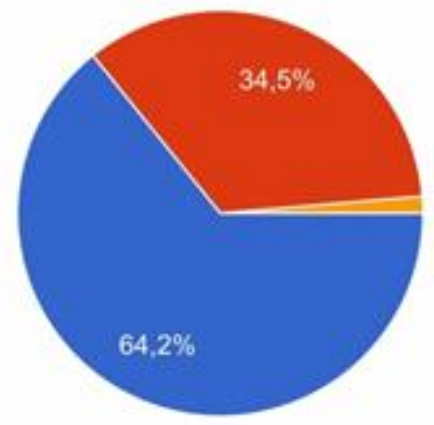

3000-5000 гривень

5000-10000 гривень

більше 10000 гривень

\section{Pис. 9. Бюджет фітнес-туру}

Для дослідження уподобань потенційних відвідувачів фітнес турів було обрано метод анкетування. Після того, як була завершена розробка анкети, за допомогою спеціальної форми в «Google Диск» розпочалось онлайн опитування, в якому прийняло участь 149 осіб.

За результатами опитування можна зробити висновок, що опитані резиденти позитивно налаштовані на фітнес тур, цільова аудиторія $є$ люди від 20 до 40 років. Які бажають розвинути фізичні та духовні якості, а також поліпшити фізичну форму та підтримувати іiі.

Як свідчать дані дослідження ринку фітнес послуг в Одеській області Одеса займає третє місто після Києва та Харкова за основними показниками фітнес-індустрії. А за покриттям фітнес-послугами займає другу позицію (покриття в Одесі складає 7,9\%). Також Одеса знаходиться на 2 місці після Києва за середньорічною вартістю відвідування 6271 грн., тобто у місті продовжує розвиватися більш дорогий сегмент фітнес-клубів [3]. Останні декілька років провідні фітнес-клуби Одеси такі, як «Форма», «Шторм», «Загублений світ» системи «Вища ліга» організовують фітнес-тури в Турцію, 
Єгипет, Туніс. Зараз вони активно впроваджують програми фітнес-турів для внутрішнього туризму на території Одеської області. Так провідний експерт 3 фітнес-індустрії, фітнес-інструктор групових програм Микола Дандаєв поділився досвідом, розказуючи, що для організації турів він здійснює пошуг по готельній базі, яка володіє спортивними залами. Обладнанням та майданчиками. Зі слів Миколи в Одеському регіоні вже є такі готелі та бази відпочинку. Так, наприклад у місті Затока є готель Ruta в наявності у якого налічуються басейни, аквапарк, спортивні ділянки, а також розташування на першій береговій лінії дасть смогу організовувати тренування на сапах. Також такого роду послуги може надати готель «Причал 80».

Шляхи підвищення ефективності розвитку фітнес-турів в Одеській області можуть бути здійснені наступним чином:

1. Створення нових закладів розміщення, які відповідають усім санітарним нормам та нормам проведення спортивних тренувань та навіть таких заходів, як фітнес-конвенції. Фітнес-конференції та виставки. Також необхідно провести реконструкцію або реновацію вже існуючих готелів. Баз відпочинку та кемпінгів.

2. Робити акцент на спортивних інноваціях (використання rubber band резинок) та створенню широкого спектру фітнес-програм, які б охоплювали широку вікову територію. Впровадження у програми обов'язкові консультації по харчуванню та створенню меню у готелях із правильним харчувальним меню.

3. Включати у програми турів екскурсійні маршрути та поєднувати фітнес-тури з етнічним, зеленим, гастрономічним екологічним та спортивноподієвим туризмом.

4. Створення стаціонарних закладів харчування, в яких будуть подаватися страви та напої місцевої кухні, але з корегуванням на правильне меню для нормалізації обміну речовин та схуднення. Це буде створюватися 3 метою, що турист який приїхав мав змогу скоштувати та насолодитися локальними стравами в момент перебування, 3 користю для свого здоров'я.

5. Проводити підготовку спеціалістів з фітнес-індустрії. Це дасть змогу на появу нових робочих місць.

6. Підтримка 3 боку держави на проведення масштабних фітнес конвенцій та популяризація нового виду спортивного туризму через 3МI та створення інтерактивної карти 3 основними фітнес-локаціями та місцями проведення спортивних конвенцій.

Висновки. Авторами було проаналізовано та розкрито потенціал для створення фітнес-турів в Україні а також охарактеризовані основні фітнестенденції в Україні та Одеській області. Виявлені основні шляхи для розвитку фітнес-турів:

популяризація здорового образу життя та правильного харчування у поєднанні з фізичним навантаженням та позитивним емоційним настроєм; зробити фітнес та активний спосіб життя доступним для кожного громадянина України; залучення інвестицій для розвитку фітнес-індустрії в цілому; користуючись методикою аналізу існуючого досвіду США та країн 
Європейського Союзу проводити дослідження стосовно основних фітнестенденцій на наступний рік.

\section{Лimepamypa:}

1. Пангелов Б.П., Заруба О.В Фітнес-туризм як різновид спортивно-оздоровчого сервісу / Б.П. Пангелов, О.В.Заруба // Молодий вчений, № 4.2 (56.2) • квітень, 2018 р.

2. Воробйова А. Світові та національні фітнес-тренди 2019 / А. Воробйова // Спортивна наука та здоров'я людини 1(1) 2019

3. Дослідження ринку фітнес-послуг України [Електронний ресурс]. - Режим доступу: https://research.fitnessconnect.com.ua/

4. Школа О. М. Сучасні фітнес-технології оздоровчо-рекреаційної спрямованості: навчальний посібник / О. М. Школа, А. В. Осіпцов // Комунальний заклад «ХГПА» ХОР. Харків, 2017. - 217 с.

\section{References:}

1. Panhelov B.P., Zaruba O.V Fitnes-turyzm yak riznovyd sportyvno-ozdorovchoho servisu / B.P. Panhelov, O.V.Zaruba // Molodyy vchenyy, № 4.2 (56.2) • kviten', 2018 r. Fitness tourism as a kind of sports and health service [in Ukrainian].

2. Vorobyova A. Svitovi ta natsional'ni fitnes-trendy 2019 / A. Vorobyova // Sportyvna nauka ta zdorov"ya lyudyny 1(1) 2019. World and national fitness trends 2019 [in Ukrainian].

3. Doslidzhennya rynku fitnes-posluh Ukrayiny. Retrieved from: https://research.fitnessconnect.com.ua/ [in Ukrainian].

4. Shkola O. M. Suchasni fitnes-tekhnolohiyi ozdorovcho-rekreatsiynoyi spryamovanosti: navchal'nyy posibnyk / O. M. Shkola, A. V. Osiptsov // Komunal'nyy zaklad «KHHPA» KHOR. - Kharkiv, 2017. - 217. Modern fitness technologies for health and recreation: a textbook [in Ukrainian]. 